\title{
Design, Synthesis, In Vivo and In Silico Anticonvulsant Activity Studies of Derivatives of 6-Amino-4-Hydroxy-2-Thio-Pyrimidine
}

\author{
Hanna I. Severina ${ }^{1 *}$, Olha 0. Skupa ${ }^{2}$, Natalya I. Voloshchuk ${ }^{3}$, Andrey R. Khairulin ${ }^{4}$, Vic- \\ toriya A. Georgiyants ${ }^{1}$ \\ 1 National University of Pharmacy, Department of Pharmaceutical Chemistry, Kharkiv, Ukraine \\ 2 National Pirogov Memorial Medical University, Department of Pharmaceutical Chemistry, Vinnytsya, Ukraine \\ 3 National Pirogov Memorial Medical University, Department of Pharmacology, Vinnytsya, Ukraine \\ 4 Institute of Organic Chemistry NAS of Ukraine, Department of Sulfur Chemistry, Laboratory of Condensed Heterocyclic \\ Compounds, Kyiv, Ukraine
}

\begin{abstract}
The aim of the given research was the targeted synthesis of anticonvulsants - (4-amino-6-hydroxy-pyrimidin-2-yl)thio-N-acetamides derivatives. Perspective of the search of anticonvulsants was evaluated by the ADMET method and docking study. The starting 6-amino-2-thiopyrimidine was obtained in result of reaction between thiourea and ethyl cyanoacetate in sodium ethoxide environment. The targeted thioacetamide derivatives were synthesized by alkylation of 6-amino-2-thiopyrimidine with the corresponding 2-chloroacetamides in DMFA environment in potassium carbonate presence. The structure of the synthesized compounds was determined using ${ }^{1} \mathrm{H}$ and ${ }^{13} \mathrm{C}$ NMR spectroscopy, LS/MS, and elemental analysis. A screening study of anticonvulsant activity on the model of pentylenetetrazole-induced seizures in rats was carried out. A lead compound - 2-((4-amino-6-hydroxypyrimidin-2-yl)thio)$\mathrm{N}-(3$-methylphenyl)acetamide - was found. The mentioned compound has shown its ability to prevented lethality, reduce the number and severity of seizures, as well as to increase latency period. Some correlation features between structure and anticonvulsant activity were determined. The obtained results of molecular docking study have shown the affinity of the lead compound to $\mathrm{GABA}_{\mathrm{A}}, \mathrm{GABA}_{\mathrm{AT}}$, Carbonic Anhydrase II, and NMDA receptors, and a possible mechanism for anticonvulsant action.
\end{abstract}

Keywords: 6-amino-2-thiopyrimidine, Acetamides, Anticonvulsant activity, ADMET, Docking.

\footnotetext{
*Corresponding author: Hanna I. Severina, e-mail: severina.ai@ukr.net Hanna I. Severina ORCID Number: 0000-0003-2894-9384 Olha 0. Skupa ORCID Number: 0000-0001-6092-078X Natalya I. Voloshchuk ORCID Number: 0000-0002-0166-9676 Andrey R. Khairulin ORCID Number: 0000-0003-4608-0838 Victoriya A. Georgiyants ORCID Number: 0000-0001-8794-8010 (Received 29 November 2019, accepted 05 December 2019)
} 


\section{INTRODUCTION}

In modern neurological practice, several generations of anticonvulsants have been used for a long time. ${ }^{1}$ Insufficient efficiency of existing antiepileptic drugs, severe side effects ${ }^{2}$, as well as development of refractory epilepsy ${ }^{3,4}$ point to the relevance of the search for new potential anticonvulsants.

Scientific achievements of the last decades concerning the establishment of anticonvulsant action mechanisms, crystalline structure of target proteins, and amino acid composition of active receptor sites, diversity of the developed in silico methods for analysis and evaluation of the ligand and receptor affinity, ADMET parameters, as well as formulated pharmacophore models of "structure-activity" correlation ${ }^{5}$, allows rationalizing the search for new AEDs.

The analysis of the structure of second- and third-generation anticonvulsants in accordance with the basic positions of the pharmacophore models of AEDs 5,6 search has shown that most of them, namely lamotrigine, vigabatrine, gabapentin, pregabaline, retigabine ${ }^{7,8}$, have in their structure free amino group, which has amide nature in the case of felbamate and levetiracetam (Fig. 1).
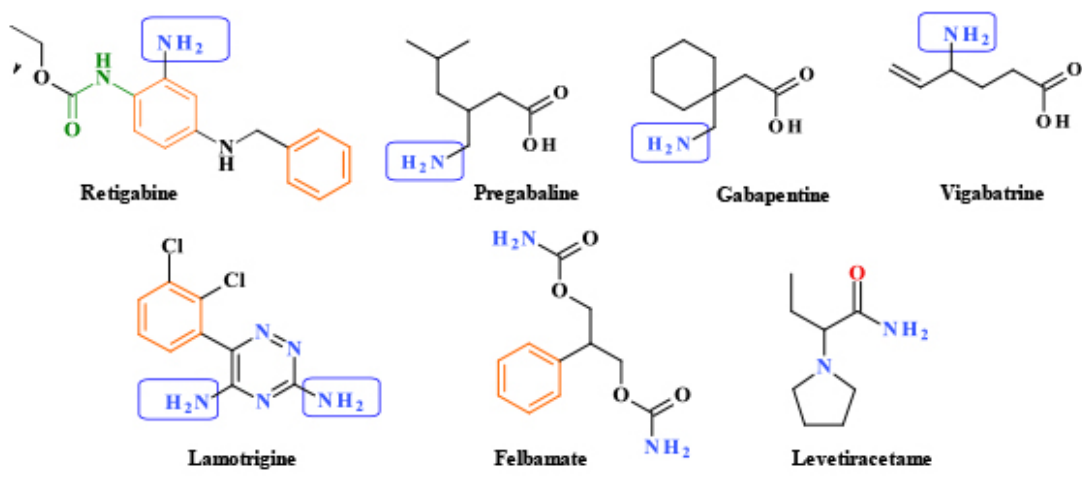

Figure 1. Chemical structure of the known anticonvulsants

The amino group acts as an electron donor by a lone electron pair, and forms conventional hydrogen bonds, which increases the affinity between the ligand and the active receptor site. The role of the amino group in interaction between the receptor is well illustrated both by in silico methods, and is proven in vitro method, for example, by interrelation between vigabatrin and GABA aminotransferase ${ }^{9}$ active site and gabapentin with branched-chain aminotransferase. $^{10}$

Structural modification of the known drugs is one of the most priority areas of the rational drug design of new anticonvulsants ${ }^{6}$, it is necessary for creation of the optimal conformation between the receptor and the ligand to improve 
its pharmacological profile. Our attention was focused on modifying the structure of the first-generation anticonvulsant - phenobarbital, which is still widely used for convulsive status epilepticus treatment in infants and children ${ }^{11}$ and is considered as the drug of choice for refractory epilepsy treatment. ${ }^{12}$ Pyrimidin-4 $(3 H)$-one derivatives, as well as its annelated derivative - quinazoline$4(3 H)$-one, having a pronounced anticonvulsant properties, have been already obtained by us using modification of its structure. Some correlation parameters between structure and anticonvulsant activity were determined has already yielded pyrimidine-4 $(3 H)$-one and with pronounced anticonvulsant properties and some patterns of structure-anticonvulsant activity have been established (Fig. 2). ${ }^{13,14}$

In the present study, our decision was to synthesize the structural analogues of the previously synthesized thiopyrimidine-4(3H)-one acetamides by changing methyl radical from the $6^{\text {th }}$ position of pyrimidine cycle to an unsubstituted amino group (Fig. 2). The donor in a hydrogen bond, which is an amino group, can significantly improve anticonvulsant activity markers, due to formation of stronger and more beneficial receptor-ligand conformation.

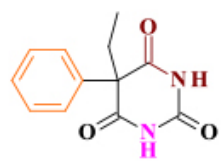

Phenobarbital

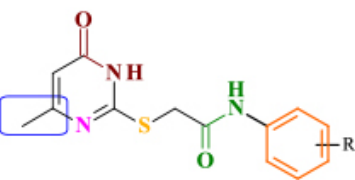

Substances with pronounced anticomvulsant activity

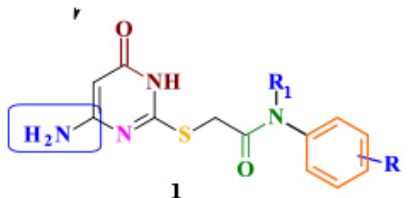

Target compounds

$\mathrm{R}=\mathbf{a ~ H} ; \mathbf{b} 3-\mathrm{Me} ; \mathbf{c} 2,6-\mathrm{Me}$; d 3-Cl; e 4-Cl f f $-\mathrm{Br}, \mathbf{g} 3-\mathrm{MeO}$; h 4-MeO; i 4-i-Pr, j H, R $\mathbf{P r}$; 1 1-naphtyi;

Figure 2. Modification direction and pharmacophore fragments enhancing anticonvulsant activity.

The available tools and models can predict the following properties: absorption, distribution, metabolism, excretion, and toxicity (ADMET). Structure-based in silico tools, as molecular docking, can predict possible interactions with the target of study. ${ }^{15}$ Therefore, for the further substantiation of expediency and prospects of the search of anticonvulsants among the substances planned for the synthesis, we carried out docking study into the $\mathrm{GABA}_{\mathrm{A}}$ receptor active site and evaluated ADMET properties - physicochemical, pharmacokinetic, drug-like and related parameters. 


\section{METHODOLOGY}

\section{ADMET}

Physicochemical properties, lipophilicity, water solubility, pharmacokinetics, druglikeness and other medicinal chemistry parameters were calculated using SwissADME ${ }^{16}$ online free tool (swissadme.ch).

\section{Molecular docking study}

Flexible molecular docking tool for the search of molecules with affinity to a specific biological target was used in the present study. The following Protein Data Bank (PDB) macromolecules were used as biological targets: GABA $R$

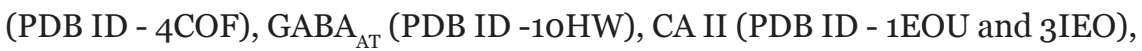
NMDAR (PDB ID - 5TP9). ${ }^{17}$ The biological targets were selected according to the literature data concerning the mechanism of action of anticonvulsants. ${ }^{18}$

IsisDraw 2.4 software was used to prepare ligands chemical structure, which were saved in mol format. Chem3D software, by means of molecular mechanical MM2 algorithm, was used to optimize the obtained structures, and saved as pdb-files. The obtained pdb-files were converted into PDBQT by AutoDockTools-1.5.6, and the number of active torsions was set as default. ${ }^{19}$

PDB files of proteins were downloaded from the protein data bank. To delete water molecules and ligand from the crystal we used discovery Studio V17.2.0.16349. Structures of proteins were saved as pdb-files. Polar hydrogens were added and saved as PDBQT in AutoDockTools-1.5.6 software. Docking study was carried out by Vina. ${ }^{19}$ For visualization, Discovery Studio V17.2.0.16349 was used.

\section{Chemistry}

Sigma-Aldrich (USA) reagents were used in the present research. Standard techniques were used for purification of the reagents. Thin layer chromatography (TLC) method using aluminium silica gel plates was used to monitor the reactions progress. Electrothermal IA9100X1 (Bibby Scientific Limited, Staffordshire, UK) digital melting point apparatus was used for determination of the melting points $\left({ }^{\circ} \mathrm{C}\right)$ in a capillary. Varian Mercury-40o (Varian Inc., Palo Alto, CA, USA) spectrometer (300 MHz) was used to record ${ }^{1} \mathrm{H}$ NMR spectra in hexadeuterodimethyl sulfoxide (DMSO-d6) using tetramethylsilane (TMS) as an internal standard (chemical shifts are in ppm). Bruker Avance 400 (100.6 $\mathrm{MHz}$ ) was used to record ${ }^{13} \mathrm{C} \mathrm{NMR}$ spectra. Chemical shifts were reported in ppm downfield from TMS as internal standards. Euro Vector EA-30oo (Eurovector SPA, Redavalle, Italy) microanalyzer was used for elemental analysis. The ob- 
tained results of the elemental analyses were within $\pm 0.4 \%$ of the theoretical values. PE SCIEX API 150EX chromatograph was used to obtain LC/MS spectra.

6-Amino-2-thio-4-hydroxy-pyrimidine was obtained according to the previously described method. ${ }^{20}$

\section{General procedure of the synthesis of S-alkylated derivatives of 6-amino-2-thio-4-hydroxy-pyrimidine 1a-k}

6-amino-2-thiouracil (10 $\mathrm{mmol}$ ) and potassium carbonate (20 mmol) mixture in $10 \mathrm{ml}$ of $\mathrm{DMF}$ was stirred at $70-80^{\circ} \mathrm{C}$ for 1 hour, then the obtained mixture was cooled to room temperature, and an appropriate chloroacetamides (10 mmol) solution in $10 \mathrm{ml}$ of DMF was added and stirred for 5 hours. The reaction mixture was filtered, and the obtained filtrate was evaporated in a vacuum. After that, the obtained residue was treated with $100 \mathrm{ml}$ of cold water. The formed precipitate was filtered, air dried, and recrystallized from an acetone-DMF mixture.

\section{2-((4-amino-6-hydroxypyrimidin-2-yl)thio)- $\mathbf{N}$-phenylacetamide} 1a. Yield: $89.0 \%$ white crystals; $\mathrm{mp}=245-247{ }^{\circ} \mathrm{C} ;{ }^{1} \mathrm{H}$ NMR (300 $\mathrm{MHz}, \mathrm{DM}-$ SO- $\left.d_{6}, \delta(\mathrm{ppm})\right): 11.65(1 \mathrm{H}, \mathrm{br} . \mathrm{s}, \mathrm{OH}), 10.01(1 \mathrm{H}, \mathrm{s}, \mathrm{NHCO}), 7.59-7.27(4 \mathrm{H}, \mathrm{m}$, H-2',3',5',6'), 7.05 (1H, t, J=7.5, H-4'), 6.56 (2H, s, NH $\left.{ }_{2}\right), 5.04(1 \mathrm{H}, \mathrm{s}, \mathrm{CH}-5)$, 4.07 (2H, s. $\left.\mathrm{SCH}_{2}\right) .{ }^{13} \mathrm{C} \mathrm{NMR}\left(100 \mathrm{MHz}, \mathrm{DMSO}-d_{6}\right.$ ): $169.4,162.8,161.8$, 158.0, 156.4, 138.5, 128.9, 128,5, 121,6, 121.4, 94.9, 56.4, 38.8. LC-MS: m/z =277.07 [M+1]. Anal. Calcd. for $\mathrm{C}_{12} \mathrm{H}_{12} \mathrm{~N}_{4} \mathrm{O}_{2} \mathrm{~S}: \mathrm{C}, 52.16 ; \mathrm{H}, 4.38 ; \mathrm{N}, 20.28 ; \mathrm{O}, 11.58 ; \mathrm{S}$, 11.6o. Found: C, 52.01; H, 4.36; N, 20.323; S, 11.58.

\section{2-((4-amino-6-hydroxypyrimidin-2-yl)thio)-N-(3-methylphenyl)}

acetamide $1 \boldsymbol{b}$. Yield: $73 \%$; white crystals; $\mathrm{mp}=227-229{ }^{\circ} \mathrm{C} ;{ }^{1} \mathrm{H}$ NMR $(300$ MHz, DMSO- $\left.d_{6}, \delta(\mathrm{ppm})\right): 11.56(1 \mathrm{H}$, br. s, NH-3), $10.00(1 \mathrm{H}, \mathrm{s}, \mathrm{NHCO}), 7.28$ (1H, s, H-2'), 7.12 (1H, t, $J=8.2, \mathrm{H}-5$ '), 7.02 (1H, d, J=7.5, H-6'), 6.52 (1H, d, $J=7.5, \mathrm{H}-4$ '), 5.05 (1H, s, CH-5), $4.00\left(2 \mathrm{H}, \mathrm{s} . \mathrm{SCH}_{2}\right), 2.13\left(3 \mathrm{H}, \mathrm{s}, \mathrm{CH}_{3}\right) .{ }^{13} \mathrm{C} \mathrm{NMR}$ (100 MHz, DMSO- $d_{6}$ ): $\quad 169.2,168.2,162.7,161.7,138.4,128.5,124.6,120.1$, 138.6, 118.6, 94.9, 38.8, 21.3. LC-MS: $\mathrm{m} / \mathrm{z}=291.09$ [M+1]. Anal. Calcd. for $\mathrm{C}_{13} \mathrm{H}_{14} \mathrm{~N}_{4} \mathrm{O}_{2} \mathrm{~S}$ : C, 53.78; H, 4.86; N, 19.30; S, 11.04. Found: C, 53.58; H, 4.84; N, 19.33; S, 11.00.

\section{2-((4-amino-6-hydroxypyrimidin-2-yl)thio)-N-(2,6-dimethylphe-} myl)acetamide 1c. Yield: (89.0\%); white crystals; $\mathrm{mp}=256-258^{\circ} \mathrm{C} ;{ }^{1} \mathrm{H}$ NMR (300 MHz, DMSO- $\left.d_{6}, \delta(\mathrm{ppm})\right): 11.58$ (1H, br. s, OH), 10.02 (1H, s, NHCO), 7.55-7.38 (3H, m, H-3', 4', 5'), 6.56 (2H, s, NH $)_{2}$ ), 5.05 (1H, s, CH-5), 4.01 (2H, s, $\left.\mathrm{SCH}_{2}\right), 2.23\left(6 \mathrm{H}, \mathrm{s}, 2 \mathrm{CH}_{3}\right)$. LC-MS: $\mathrm{m} / \mathrm{z}=305.10$ [M+1]. Anal. Calcd. for $\mathrm{C}_{14} \mathrm{H}_{16} \mathrm{~N}_{4} \mathrm{O}_{2} \mathrm{~S}: \mathrm{C}, 55.25 ; \mathrm{H}, 5.30 ; \mathrm{N}, 18.41 ; \mathrm{S}, 10.53$. Found: C, 55.06; H, 5.28; N, 18.47; S, 10.49 . 
2-((4-amino-6-hydroxypyrimidin-2-yl)thio)-N-(3-chlorophenyl) acetamide 1d. Yield: 77.0\%; white crystals; $\mathrm{mp}=234-236{ }^{\circ} \mathrm{C} ;{ }^{1} \mathrm{H}$ NMR $(300$ MHz, DMSO- $\left.d_{6}, \delta(\mathrm{ppm})\right): 11.6 \mathrm{o}(1 \mathrm{H}, \mathrm{br} . \mathrm{s}, \mathrm{OH}), 10.02(1 \mathrm{H}, \mathrm{s}, \mathrm{NHCO}), 7.3 \mathrm{O}(1 \mathrm{H}$, s, H-2'), 7.12 (1H, t, $J=8.2, \mathrm{H}-5^{\prime}$ ), 7.02 ( $1 \mathrm{H}, \mathrm{d}, J=7.5, \mathrm{H}-6$ '), 6.56 (2H, s, $\mathrm{NH}_{2}$ ), 6.52 (1H, d, $J=7.5, \mathrm{H}-4$ '), 5.07 ( $1 \mathrm{H}, \mathrm{s}, \mathrm{CH}-5), 4.02\left(2 \mathrm{H}, \mathrm{s} . \mathrm{SCH}_{2}\right.$ ). LC-MS: m/z $=311.23[\mathrm{M}+1]$. Anal. Calcd. for $\mathrm{C}_{12} \mathrm{H}_{11} \mathrm{ClN}_{4} \mathrm{O}_{2} \mathrm{~S}: \mathrm{C}, 46.38 ; \mathrm{H}, 3.57 ; \mathrm{N}, 18.03 ; \mathrm{S}$, 10.32. Found: C, 46.22; H, 3.56; N, 18.09; S, 10.28 .

\section{2-((4-amino-6-hydroxypyrimidin-2-yl)thio)-N-(4-chlorophenyl)} acetamide 1e. Yield: $85.0 \%$; white crystals; $\mathrm{mp}=245-247^{\circ} \mathrm{C} ;{ }^{1} \mathrm{H}$ NMR $(300$ MHz, DMSO- $\left.d_{6}, \delta(\mathrm{ppm})\right): 11.65(1 \mathrm{H}, \mathrm{br} . \mathrm{s}, \mathrm{OH}), 10.27(1 \mathrm{H}, \mathrm{s}, \mathrm{NHCO}), 7.6 \mathrm{O}(2 \mathrm{H}$, d $J=9, \mathrm{H}-3^{\prime}, 5$ '), 7.37 (2H, d, $\left.J=9, \mathrm{H}-2^{\prime}, 5^{\prime}\right), 6.56$ (2H, s, $\mathrm{NH}_{2}$ ), 5.12 (1H, s, CH-5), $\left.4.02(2 \mathrm{H}, \mathrm{s.} \mathrm{SCH})_{2}\right) .{ }^{13} \mathrm{C} \mathrm{NMR}\left(100 \mathrm{MHz}\right.$, DMSO- $d_{6}$ ): $169.4,168.2,162.8,161.8$, 136.6, 133.3, 129.o (2C), 129.0, 120.4 (2C), 38.8. LC-MS: $\mathrm{m} / \mathrm{z}=311.13$ [M+1]. Anal. Calcd. for $\mathrm{C}_{12} \mathrm{H}_{11} \mathrm{ClN}_{4} \mathrm{O}_{2} \mathrm{~S}: \mathrm{C}, 46.38 ; \mathrm{H}, 3.57 ; \mathrm{N}, 18.03 ; \mathrm{S}, 10.32$. Found: C, 46.24; H, 3.56; N, 18.06; S, 10.29 .

2-((4-amino-6-hydroxypyrimidin-2-yl)thio)-N-(4-bromophenyl) acetamide 1f. Yield: $80.0 \%$; white crystals; $\mathrm{mp}=258-260{ }^{\circ} \mathrm{C} ;{ }^{1} \mathrm{H}$ NMR $(300$ MHz, DMSO-d 6, $\delta$ (ppm)): 11.68 (1H, br. s, OH), 10.22 (1H, s, NHCO), 7.61 (2H, d, $\left.J=8, \mathrm{H}-3^{\prime}, 5^{\prime}\right), 7.42\left(2 \mathrm{H}, \mathrm{d}, J=8, \mathrm{H}^{\prime} 2^{\prime}, 6^{\prime}\right), 6.85\left(2 \mathrm{H}, \mathrm{s}, \mathrm{NH}_{2}\right), 5.05(1 \mathrm{H}$, s, CH-5), $4.04\left(2 \mathrm{H}, \mathrm{s} . \mathrm{SCH}_{2}\right)$. LC-MS: $\mathrm{m} / \mathrm{z}=356.98[\mathrm{M}+1]$. Anal. Calcd. for $\mathrm{C}_{12} \mathrm{H}_{11} \mathrm{BrN}_{4} \mathrm{O}_{2} \mathrm{~S}: \mathrm{C}, 40.58 ; \mathrm{H}, 3.12 ; \mathrm{N}, 15.77 ; \mathrm{S}, 9.03$. Found: C, 40.44; H, 3.10; N, $15.82 ; \mathrm{S}, 9.02$.

\section{2-((4-amino-6-hydroxypyrimidin-2-yl)thio)-N-(3-methoxyphenyl)}

acetamide 1g. Yield: $73.0 \%$; white crystals; $\mathrm{mp}=208-210{ }^{\circ} \mathrm{C} ;{ }^{1} \mathrm{H}$ NMR $(300$ MHz, DMSO-d 6, $\delta$ (ppm)): 11.52 (1H, br. s, OH), $10.01(1 \mathrm{H}, \mathrm{s}, \mathrm{NHCO}), 7.28$ (1H, s, H-2'), $7.12\left(1 \mathrm{H}, \mathrm{t}, J=8.2, \mathrm{H}-5^{\prime}\right), 7.02\left(1 \mathrm{H}, \mathrm{d}, J=7.5, \mathrm{H}-6^{\prime}\right), 6.89(1 \mathrm{H}, \mathrm{d}$, $J=7.5, \mathrm{H}-4$ '), $6.51\left(2 \mathrm{H}, \mathrm{s}, \mathrm{NH}_{2}\right), 5.04(1 \mathrm{H}, \mathrm{s}, \mathrm{CH}-5), 4.00\left(2 \mathrm{H}, \mathrm{s} . \mathrm{SCH}_{2}\right), 3.75(3 \mathrm{H}$, s, $\mathrm{OCH}_{3}$ ). LC-MS: $\mathrm{m} / \mathrm{z}=307.08[\mathrm{M}+1]$. Anal. Calcd. for $\mathrm{C}_{13} \mathrm{H}_{14} \mathrm{~N}_{4} \mathrm{O}_{3} \mathrm{~S}: \mathrm{C}, 50.97$; H, 4.61; N, 18.29; S, 10.47. Found: C, 50.81; H, 4.60; N, 18.36; S, 10.44 .

2-((4-amino-6-hydroxypyrimidin-2-yl)thio)-N-(4-methoxyphenyl) acetamide $1 \boldsymbol{h}$. Yield:76.0\%; white crystals; $\mathrm{mp}=255-257^{\circ} \mathrm{C} ;{ }^{1} \mathrm{H}$ NMR $(300$ MHz, DMSO-d 6, $\delta$ (ppm)): 11.52 (1H, br. s, OH), 10.20 (1H, s, NHCO), 7.54 (2H, d $\left.J=8, \mathrm{H}-3^{\prime}, 5^{\prime}\right), 7.30$ (2H, d, $\left.J=8, \mathrm{H}-2^{\prime}, 6^{\prime}\right), 6.50\left(2 \mathrm{H}, \mathrm{s}, \mathrm{NH}_{2}\right), 5.10(1 \mathrm{H}, \mathrm{s}$, $\mathrm{CH}-5), 4.09\left(2 \mathrm{H}, \mathrm{s} . \mathrm{SCH}_{2}\right), 3.75\left(3 \mathrm{H}, \mathrm{s}, \mathrm{OCH}_{3}\right)$. LC-MS: $\mathrm{m} / \mathrm{z}=307.06[\mathrm{M}+1]$. Anal. Calcd. for $\mathrm{C}_{13} \mathrm{H}_{14} \mathrm{~N}_{4} \mathrm{O}_{3} \mathrm{~S}: \mathrm{C}, 50.97 ; \mathrm{H}, 4.61 ; \mathrm{N}, 18.29 ; \mathrm{S}, 10.47$. Found: C, 50.89; H, 4.60; N, 18.36; S, 10.44 . 
2-((4-amino-6-hydroxypyrimidin-2-yl)thio)-N-(4-isopropylphenyl)acetamide 1i. Yield: $66.0 \%$; white crystals; $\mathrm{mp}=255-257^{\circ} \mathrm{C}$; ${ }^{1} \mathrm{H}$ NMR (30o MHz, DMSO-d 6, $\delta$ (ppm)): 11.60 (1H, br. s, OH), $10.01(1 \mathrm{H}, \mathrm{s}, \mathrm{NHCO})$, 7.48 (2H, d, $\left.J=8.4, \mathrm{H}-3^{\prime}, 5^{\prime}\right), 7.17$ (2H, d, $\left.J=8.4, \mathrm{H}^{2} 2^{\prime}, 6^{\prime}\right), 6.51\left(2 \mathrm{H}, \mathrm{s}, \mathrm{NH}_{2}\right), 5.04$ (1H, s, CH-5), 3.99 (2H, s. $\mathrm{SCH}_{2}$ ), 2.85-2.79 (1H, m, CH), $1.18\left(6 \mathrm{H}, \mathrm{s} .2 \mathrm{CH}_{3}\right)$. LC-MS: $\mathrm{m} / \mathrm{z}=319.12[\mathrm{M}+1]$. Anal. Calcd. for $\mathrm{C}_{15} \mathrm{H}_{18} \mathrm{~N}_{4} \mathrm{O}_{2} \mathrm{~S}: \mathrm{C}, 56.59 ; \mathrm{H}, 5.70 ; \mathrm{N}$, 17.60; S, 10.07. Found: C, 56.49; H, 5.68; N, 17.58; S, 10.02.

2-((4-amino-6-hydroxypyrimidin-2-yl)thio)-N-isopropyl-N-phenylacetamide 1j. Yield: $72.0 \%$; white crystals; $\mathrm{mp}=235-237^{\circ} \mathrm{C}$; ${ }^{1} \mathrm{H}$ NMR (300 MHz, DMSO-d 6, $\delta(\mathrm{ppm})): 11.60(1 \mathrm{H}$, br. s, OH), 7.62-7.30 $(4 \mathrm{H}, \mathrm{m}$, H-2',3',5',6'), 7.05 (1H, t, J=7.5, H-4'), 6.56 (2H, s, NH N $^{2}, 5.02(1 \mathrm{H}, \mathrm{s}, \mathrm{CH}-5)$, $4.02\left(2 \mathrm{H}, \mathrm{s} . \mathrm{SCH}_{2}\right), 2.85-2.79(1 \mathrm{H}, \mathrm{m}, \mathrm{CH}), 1.18\left(6 \mathrm{H}, \mathrm{s} .2 \mathrm{CH}_{3}\right) .{ }^{13} \mathrm{C} \mathrm{NMR}(100$ MHz, DMSO- $d_{6}$ ): $169.2,165.7,162.8,161.8,158.0,137.9,128.9,128.5,128,0$, 127.5 , 94.6, 59,8, 36.9, 20.6 (2C) LC-MS: m/z = 319.12 [M+1]. Anal. Calcd. for $\mathrm{C}_{15} \mathrm{H}_{18} \mathrm{~N}_{4} \mathrm{O}_{2} \mathrm{~S}: \mathrm{C}, 56.59 ; \mathrm{H}, 5.70 ; \mathrm{N}, 17.60 ; \mathrm{S}, 10.07$. Found: C, 56.45; H, 5.69; N, 17.64; S, 10.00.

\section{2-((4-amino-6-hydroxypyrimidin-2-yl)thio)-N-(naphthalen-1-yl)} acetamide $1 \boldsymbol{k}$. Yield: 70.0\%; white crystals; $\mathrm{mp}=297-299^{\circ} \mathrm{C} ;{ }^{1} \mathrm{H}$ NMR (300 MHz, DMSO-d 6, $\delta$ (ppm)): $11.62(1 \mathrm{H}$, br. s, OH), $10.02(1 \mathrm{H}, \mathrm{s}, \mathrm{NHCO}), 7.98-$ 7.79 (4H, m, Ar), 7.68-7.56 (3H, m, Ar), 6.56 (2H, s, NH N $_{2}, 5.06(1 \mathrm{H}, \mathrm{s}, \mathrm{CH}-5)$, 4.08 (2H, s. $\mathrm{SCH}_{2}$ ). LC-MS: $\mathrm{m} / \mathrm{z}=327.09[\mathrm{M}+1]$. Anal. Calcd. for $\mathrm{C}_{16} \mathrm{H}_{14} \mathrm{~N}_{4} \mathrm{O}_{2} \mathrm{~S}$ : C, 58.88; H, 4.32; N, 17.17; S, 9.82. Found: C, 58.78; H, 4.30; N, 17.19; S, 9.80.

\section{Anticonvulsant activity}

Animals

75 adult male rats (130-150 g) and adult random-bred albino mice of either sex weighing 130-150g were used for research. The animals were kept in the National Pirogov Memorial Medical University (Vinnytsya, Ukraine) vivarium, under the standard conditions with a temperature of $\left(22 \pm 1^{\circ} \mathrm{C}\right)$, relative humidity of $(55 \pm 15 \%)$, free access to food and water, and a 12-hour light/darkness cycle (8.00-20.00), respectively. The animals were treated in accordance with «Directive 2010/63/EU of the European Parliament and of the Council of 22 September 2010 on the protection of animals used for scientific purposes», with the procedures and requirements of the State Expert Centre of the Ministry of Health of Ukraine and with the rules of European Convention for the Protection of Vertebrate Animals used for Experimental and Other Scientific Purposes (Strasbourg, 1986), resolution of the First National Congress on Bioethics (Kyiv, 2001), with the Law of Ukraine National Congress on Bioethics 
(Kyiv, 2001) and with the Law of Ukraine №3447-IV «On Protection of Animals from Cruel Treatment» dated 02.21.2006.

Animals were divided to experimental and control groups at random. The test substances were and injected with an oral cannula through a probe (volume 0.5 $\mathrm{ml} / 100 \mathrm{~g}$ body weight of rats) after dissolution in 1\% starch gel. $20 \mathrm{mg} / \mathrm{kg}$ dose was chosen for the screening. Phenobarbital and lamotrigine were used as the reference compounds and were administered in the same manner at their mean anticonvulsant doses of $20 \mathrm{mg} / \mathrm{kg}$ body weight. The experiment duration was calculated according to the data about the maximum anticonvulsant activity level of the drug described in the literature data. ${ }^{21}$ In the control group of animals, an equivalent amount of solvent was administered. Pentylentetrazoleinduced seizures were caused in period 9:00 - 11:00, in order to minimize circadian rhythms influence. ${ }^{22}$

\section{Pentylenetetrazole-Induced Seizures}

Pentylentetrazole ( Sigma», USA) at a dose of $80 \mathrm{mg} / \mathrm{kg}$ was used as a single subcutaneous injection to the laboratory animals to start a convulsive attack. A freshly prepared suspension of experimental compounds and reference drugs phenobarbital and lamotrigine $(20 \mathrm{mg} / \mathrm{kg})$ were given to the animals. The anticonvulsant activity level was estimated according to the latent period duration, the severity and duration of seizures in minutes and the lethality rate of mice.

The severity of seizures was evaluated by a 5-point scale, considering the following criteria (including the number of died animals): ${ }^{23} \mathrm{O}$ - no seizure activity; 1 - hyperkinesia; 2 - trembling, twitching; 3 - clonic seizures of upper limbs with the rise on their lower limbs; 4 - pronounced tonic-clonic seizures, the animal's fall to the side, available phase of tonic extension; 5 - repeated tonic-clonic seizures, loss of posture, death. Anticonvulsant effect was considered an animal protection based on the clonic and tonic seizures and the lethality.

\section{Statistical analysis}

The obtained data was reported as the mean \pm standard error of the mean. Comparison among the studied groups was analyzed by one-way ANOVA with the post hoc Dunnett's multiple comparison test to judge significance of the observed effect (Statistical package for social sciences, SPSS 16.o, USA). P values $\leq$ o, 05 was considered as significant.

\section{RESULTS AND DISCUSSION}

Construction of possible candidates' virtual database for the synthesis was carried out using logical and structural analysis of the literature ${ }^{24}$ and our own 
experience ${ }^{13,14}$ regarding the effect of amide fragment substituents on anticonvulsant activity. As it is shown on Figure 2, modification of the 6-amino-2-thioxo-pyrimidin-4-one basic structure occurred by implementation of arylacetamide fragment with 11 different bioactive substituents.

Scheduled for synthesis compounds are barbiturates structural analogues, whose mechanism of action is realized by allosteric site binding to the proteins type-A $\gamma$-aminobutyric acid receptors $\left(\mathrm{GABA}_{\mathrm{A}} \mathrm{Rs}\right)$. AutoDockTools1.5 virtual screening was used to predict the affinity of the studied compounds $\mathbf{1 a}-\mathbf{k}$ with $\mathrm{GABA}_{\mathrm{A}} \mathrm{R}(\mathrm{PDB} 4 \mathrm{COF})^{25}$. Phenobarbital was used as the reference ligand to compare binding energy, due to its binding energy to $\mathrm{GABA}_{\mathrm{A}} \mathrm{R}$ active site of was $-7.6 \mathrm{kcal} / \mathrm{mol}$. All the tested $\mathbf{1 a}-\mathbf{k}$ ligands showed a significant $\mathrm{GABA}_{\mathrm{A}} \mathrm{R}$ affinity with low scoring functions at the same or slightly worse level $(1 \mathrm{~g}, \mathrm{~h}, \mathrm{j})$ with the reference drug (Table 1). The obtained data confirm the prospect of the search for anticonvulsants among the mentioned derivatives, and allow us to choose pentylenetetrazole (PTZ) model of seizures for primary screening, since PTZ is a classic proconvulsant which action is caused by $\mathrm{GABA}_{\mathrm{A}}$ site of the benzodiazepine receptor complex suppression and the intensity of GABA-ergic inhibitory processes in the $\mathrm{CNS}$ reducing.

Another confirmation of the scheduled studies expediency was the obtained results of ADMET parameters calculation (Table 1), which predict $\mathbf{1 a - k}$ acetamides to be orally bioavailable (i.e. the drug-likeness). Table 1 shows just several calculated parameters, namely the numerical features of the physicochemical properties, lipophilicity and drug likeness according to 6 different filters. 
Table 1. ADMET properties for target compounds 1a-k

\begin{tabular}{|c|c|c|c|c|c|c|c|c|c|c|c|}
\hline \multirow[t]{2}{*}{ Properties } & \multicolumn{11}{|c|}{ Compounds } \\
\hline & 1a & $1 \mathrm{~b}$ & $1 \mathrm{c}$ & $1 d$ & $1 e$ & $1 f$ & $1 \mathrm{~g}$ & $1 \mathrm{~h}$ & $1 i$ & $1 \mathrm{j}$ & $1 \mathrm{k}$ \\
\hline \multicolumn{12}{|c|}{$\begin{array}{l}\text { Docking in active site of } \\
\mathrm{GABA}_{\mathrm{A}}(\mathrm{PDB} 4 \mathrm{COOF})\end{array}$} \\
\hline $\begin{array}{l}\text { Binding energy } \\
\text { (kcal/mol) }\end{array}$ & -7.4 & -7.5 & -7.3 & -7.2 & -7.3 & -7.4 & -6.2 & -6.7 & -7.4 & -6.2 & -7.8 \\
\hline \multicolumn{12}{|c|}{ Physicochemical Properties } \\
\hline Molecular weight & 276 & 290 & 304 & 310 & 310 & 355 & 306 & 306 & 318 & 318 & 326 \\
\hline Rotatable bonds & 5 & 5 & 5 & 5 & 5 & 5 & 6 & 6 & 6 & 6 & 5 \\
\hline H-bond acceptors & 4 & 4 & 4 & 4 & 4 & 4 & 5 & 5 & 4 & 4 & 4 \\
\hline H-bond donors & 3 & 3 & 3 & 3 & 3 & 3 & 3 & 3 & 3 & 2 & 3 \\
\hline Molar Refractivity & 74.0 & 78.9 & 83.9 & 79.0 & 79.0 & 81.7 & 80.5 & 80.5 & 88.5 & 88.5 & 91.5 \\
\hline $\operatorname{TPSA}^{1}(\AA)$ & 126.43 & 126.4 & 126.43 & 126.43 & 126.43 & 126.43 & 135.66 & 135.66 & 126.43 & 117.64 & 126.43 \\
\hline \multicolumn{12}{|l|}{ Lipophilicity } \\
\hline iLOGP & 1.29 & 1.87 & 1.97 & 1.79 & 1.80 & 1.94 & 1.80 & 1.76 & 2.37 & 2.50 & 1.97 \\
\hline XLOGP3 & 1.58 & 1.95 & 2.31 & 2.21 & 2.21 & 2.27 & 1.55 & 1.55 & 2.71 & 2.56 & 2.83 \\
\hline WLOGP & 1.31 & 1.62 & 1.93 & 1.97 & 1.97 & 2.07 & 1.32 & 1.32 & 2.44 & 2.31 & 2.47 \\
\hline MLOGP & 0.73 & 0.59 & 0.86 & 1.27 & 1.27 & 1.40 & 0.06 & 0.06 & 1.11 & 1.11 & 1.58 \\
\hline SILICOS-IT Log P & 0.76 & 1.26 & 1.76 & 1.41 & 1.41 & 1.45 & 0.81 & 0.81 & 1.84 & 1.26 & 1.79 \\
\hline Consensus Log P & 1.14 & 1.46 & 1.77 & 1.73 & 1.73 & 1.83 & 1.11 & 1.10 & 2.09 & 1.95 & 2.13 \\
\hline \multicolumn{12}{|l|}{ Druglikeness } \\
\hline Lipinski violations & 0 & 0 & 0 & 0 & 0 & 0 & 0 & 0 & 0 & 0 & 0 \\
\hline Ghose violations & 0 & 0 & 0 & 0 & 0 & 0 & 0 & 0 & 0 & 0 & 0 \\
\hline Veber violations & 0 & 0 & 0 & 0 & 0 & 0 & 0 & 0 & 0 & 0 & 0 \\
\hline Egan violations & 0 & 0 & 0 & 0 & 0 & 0 & 1 & 1 & 0 & 0 & 0 \\
\hline Muegge violations & 0 & 0 & 0 & 0 & 0 & 0 & 0 & 0 & 0 & 0 & 0 \\
\hline $\begin{array}{l}\text { Bioavailability } \\
\text { Score violations }\end{array}$ & 0.55 & 0.55 & 0.55 & 0.55 & 0.55 & 0.55 & 0.55 & 0.55 & 0.55 & 0.55 & 0.55 \\
\hline${ }^{1}$ Total polar surfac & & & & & & & & & & & \\
\hline
\end{tabular}

In result of water solubility parameter test, all the studied compounds were moderately soluble. According to pharmacokinetics parameters - high gastrointestinal absorption, partial blood-brain barrier permeability (except 1g, h do not penetrate the BBB), the absence of inhibitory effect on CYP450 enzymes and are not P-glycoprotein substrates. 1f compound having 4-bromophenyl substituent showed one violation in lead likeness (medicinal chemistry) parameter: its molecular weight was 355.21 instead of the desired $250 \leq \mathrm{MW} \leq 350$. Since molecular weight deviation was not significant, $\mathbf{1 f}$ compound was left for the further research. Compounds $\mathbf{1 g}, \mathbf{h}$ having methoxy groups in phenyl radical also had one violation in the drug likeness parameter, namely the Egan filter: topological polar surface area was TPSA $>131.6$, while the optimal range was 20 
and $130 \AA^{2}$. The given descriptor is quite important, due to its correlation with passive molecular transport through membranes including blood-brain barrier (BBB). Given the fact that the deviation was only $1.6 \AA^{2}$ and, according to Kelder $^{26}$ data, the allowable PSA value was $<150 \AA^{2}, \mathbf{1 g}, \mathbf{h}$ compounds were left for the further studies. Negative prognosis for $\mathrm{BBB}$ penetration of compounds may be associated only with relatively high TPSA values. It's worth mentioning that other criteria are rather important for effective AEDs, and their calculation for the test substances 1a-k was positive:

- lipophilicity, an indicator that is considered to be the key property for drug development, especially CNS affecting ones; ${ }^{27,28}$

- H-bond donors and acceptors quantity and molecular weigh, directly affecting on ligand binding sites formation in proteins-targets; ${ }^{29}$

- whether the substance is a glycoprotein P-gp substrate, because one of the key $\mathrm{P}$-gp roles is the CNS protection from xenobiotics ${ }^{30}$, including AED. ${ }^{31}$ Most of the modern AED (gabapentin, felbamate, topiramate, etc.) are P-gp substrates, and this is considered to be a reason of pharmacoresistant epilepsy;

- whether the substance is a cytochromes P450 inhibitor. All AEDs methabolism, excluding levetiracetam and lamotrigine, is realized by cytochromes P450 subfamily CYP1-3, moreover, the most important enzymes are CYP1A2, CYP2C9, CYP2C19, CYP2D6, CYP3A3, CYP3A4 ${ }^{32}$ Therefore, inhibition of the mentioned enzymes may lead to a large number of side effects.

To form key intermediate rings - 6-amino-2-thioxo-pyrimidine-4-one - we used already developed approach ${ }^{13}$, but ethyl acetoacetate was substituted to cyanoacetate (Scheme 1). The reagents condensation was carried out in refluxing absolute ethanol with a 2.6-2.8-fold molar excess of sodium ethoxide.

The existence of 6-amino-2-thio-pyrimidin-4-one in several tautomeric forms (lactam A/lactim B) (scheme 1) substantiates the possibility of several alkylation directions depending on the reaction conditions. ${ }^{33,34}$ Since we decided to modify the structure of previously obtained methyl derivatives, for the target products 1a-k synthesis, we used the same conditions leading to S-alkylated thiopyrimidines. ${ }^{13,35}$ We carried out the interaction between 6-amino-2-thiopyrimidine and the corresponding 2-chloroacetamides in dimethylformamide environment and the presence of potassium carbonate excess at a temperature of $70-80^{\circ} \mathrm{C}$. According to the TLC, mass-spectroscopy and ${ }^{1} \mathrm{H}$ NMR-spectroscopy data, the alkylation is selective with the following S-derivatives formation. The synthesized 1a-k substances are white crystalline substances, easily soluble in dioxane, dimethylformamide, and insoluble in water. The structure and purity 
of the obtained compounds were confirmed by elemental analysis, ${ }^{1} \mathrm{H} \mathrm{NMR},{ }^{13} \mathrm{C}$ NMR spectroscopy, and LC/MS. ${ }^{1} \mathrm{H}$ NMR spectra of the synthesized $\mathbf{1 a}-\mathbf{k}$ compounds have shown the singlet signal of the acetamide residue proton group at $\delta$ 10.16-10.01 ppm (excluding lj substance), the singlet signal of methylene $\mathrm{SCH}_{2}$-group in area of 4.12-4.00 ppm, and a two-proton singlet signal of an amino group in the 6 position at $6.51-6.32 \mathrm{ppm}$.

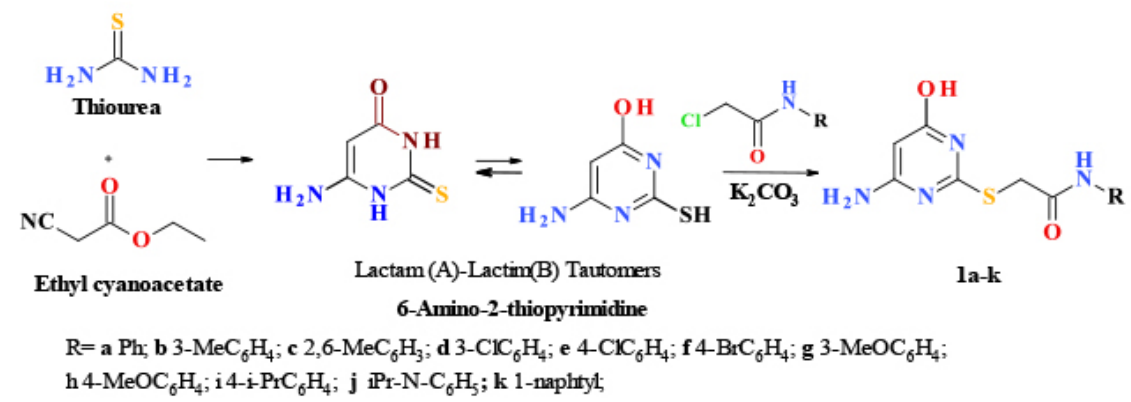

Scheme 1. Alkylation of 6-amino-2-thiopyrimidine of 2-chloroacetamides

The aryl radical protons resonate in the region of $\delta$ 7.61-7.22 ppm according to the substituent's location. Other signals were interpreted in comparison with the spectra of the previously described 6-methyl-2-thioxo-2,3-dihydropyrimidin-4(1H)-one acetamides: extended singlet signal at 11.50-11.52 ppm. was attributed to $\mathrm{OH}$ group proton, since proton $\mathrm{NHC}=\mathrm{O}$ in the third position of the pyrimidine cycle resonates in a weaker field $\delta$ 12.52-12.43 ppm at its existence in the lactam form; $\mathrm{CH}$ signal shift at the 5 position of the pyrimidine cycle into the strong field region by almost $1 \mathrm{ppm}-5.02-4.99 \mathrm{ppm}$ in 4-hydroxypyrimidines 1a-k against 6.05-5.98 ppm in pyrimidin-4-ones ${ }^{13}$, indicating that there is no effect of a strong electron-withdrawing carbonyl group on compounds 1a$\mathbf{k}$, which also allows pointing to the fact that the synthesized compounds are 2-((4-amino-6-hydroxypyrimidin-2-yl)thio)-N-acetamides.

The synthesized 1a-k compounds were examined for anticonvulsant activity using pentylenetetrazole-induced model of seizures in rats. Pentylenetetrazole administration led to convulsions development in all animals of the control group: the latent period duration averaged 4.7 minutes; convulsion attack duration was 9.7 minutes (Table 2). Convulsions were accompanied by tonic-clinical seizures, a clear phase of tonic extension was also observed, and lethality in the group was $100 \%$. Phenobarbital significantly prevented convulsions development in all animals. After lamotrigine administration in rats, pentylenetetrazole caused some manifestations of seizures (convulsive twitching, jumps and tonic contractions of the forelimbs), but statistically significantly prolonged the 
latency period in 5.8 times; the severity and duration of seizures decreased significantly, compared to the control group, and lethality in the group was $20 \%$.

Pharmacological screening resulted that all the studied compounds 1a-k in one or another way demonstrated their anticonvulsant effect on the model of pentylenetetrazole-induced seizures in rats. After their administration, a tendency to prolong the latency period at least in 2.3 times was found, lethality has changed from $60 \%$ to $100 \%$, and severity and duration of seizures decreased (Table 2).

Compound $\mathbf{1 b}$ with a 3-methyl substituent in phenyl radical considered being the absolute lead. It significantly improved all experimental convulsion indicators without exception: the latency period increased in 5.6 times ( $p<0.05)$, the severity of seizures decreased in 12.4 times (o.4 points instead of 4.96 in the control group), and duration of convulsions decreased more than in 12 times (up to $0.80 \pm 0.8^{*}$ min instead of $\left.9.70 \pm 0.90 \mathrm{~min}, \mathrm{p}<0.05\right)$. Comparing of the obtained screening results of 3-methyl-(1b) and 2,6-dimethylphenylacetamides (1c) points to a worsening of anticonvulsant activity markers as a result of increase of methyl groups number: the latency period increased only in 3.5 times, lethality protection was $80 \%$, and any influence on duration of seizures was not observed.

Table 2. Influence of the investigated substances on the pentylenetetrazole-induced seizures in rats

\begin{tabular}{|c|c|c|c|c|c|c|}
\hline $\begin{array}{c}\text { Groups } \\
\text { of animals }\end{array}$ & $\begin{array}{l}\text { Number of } \\
\text { rats in the } \\
\text { group }\end{array}$ & $\begin{array}{l}\text { Dose, } \\
\mathrm{mg} / \mathrm{kg}\end{array}$ & $\begin{array}{l}\text { Duration of } \\
\text { the latent } \\
\text { period, min }\end{array}$ & $\begin{array}{c}\text { Duration } \\
\text { of seizures, } \\
\text { min }\end{array}$ & $\begin{array}{l}\text { Lethality } \\
\text { abs. units } \\
(\%)\end{array}$ & $\begin{array}{c}\text { Severity } \\
\text { of seizures, } \\
\text { (points) }\end{array}$ \\
\hline Control & $n=10$ & - & $4.7 \pm 0.30$ & $9.70 \pm 0.90$ & $10(100 \%)$ & 4,96 \\
\hline $1 a$ & $n=5$ & 20 & $11.2 \pm 1.6^{*}$ & $10.8 \pm 2.2$ & $0^{*}$ & 2.1 \\
\hline $1 \mathrm{~b}$ & $n=5$ & 20 & $26.6 \pm 0.7^{\star}$ & $0.80 \pm 0.8^{*}$ & $0^{*}$ & 0.4 \\
\hline 10 & $n=5$ & 20 & $16,0 \pm 5,8^{*}$ & $8,2 \pm 3,4^{*}$ & $1(20 \%)$ & 2,0 \\
\hline $1 d$ & $n=5$ & 20 & $14.4 \pm 4.0^{*}$ & $7.6 \pm 2.0$ & $2(40 \%)$ & 3.2 \\
\hline $1 e$ & $n=5$ & 20 & $12,4 \pm 2.6^{*}$ & $13.8 \pm 3.5^{\star}$ & $2(40 \%)$ & 3.2 \\
\hline $1 f$ & $n=5$ & 20 & $20.0 \pm 3.0^{*}$ & $1.0 \pm 1.0^{\star} / \#$ & $0^{*}$ & 0.4 \\
\hline $1 \mathrm{~g}$ & $n=5$ & 20 & $11,2 \pm 1,3^{*}$ & $4,4 \pm 0,5^{\star}$ & $1(20 \%)$ & 2,2 \\
\hline 1h & $n=5$ & 20 & $16.0 \pm 5,8$ & $8.2 \pm 3,4$ & $1(20 \%)$ & 2.4 \\
\hline $1 \mathrm{i}$ & $n=5$ & 20 & $12,8 \pm 2,8^{*}$ & $9,0 \pm 0,8$ & $1(20 \%)$ & 2,0 \\
\hline $1 \mathrm{j}$ & $n=5$ & 20 & $16.0 \pm 1.2^{*}$ & $6.6 \pm 2.5$ & $1(20 \%)$ & 2.30 \\
\hline $1 \mathrm{k}$ & $n=5$ & 20 & $11.2 \pm 1.3^{*}$ & $4.4 \pm 0.5^{\star}$ & $0^{*}$ & 2.2 \\
\hline Phenobarbital & $n=5$ & 20 & $30.0 \pm 0.0^{*}$ & $0^{*}$ & $0^{*}$ & 0 \\
\hline Lamotrigine & $n=5$ & 20 & $27.6 \pm 0.8^{*}$ & $2.40 \pm 0.40^{*}$ & $1(20 \%)$ & 2.20 \\
\hline
\end{tabular}

Footnotes: $\quad \mathrm{n}$ - a number of animals in the group

* - compared to control group indicators $\mathrm{p}<0.05$ 
Compound 1f with 4-bromophenyl substituent also showed significant anticonvulsant properties: it significantly extended the latency period in 4.25 times, duration of seizures was only 1 minute, instead of 9.7 in the control group, and their severity was 0.4 points, it's also worth mentioning that this compound completely prevented lethality in the appropriate group of animals.

Compound 1a with unsubstituted phenyl radical completely prevented lethality in the appropriate group of animals, prolonged the latency period by 2.4 times, but it did not affect the duration of seizures, although their severity was much lower - 2.1 points instead of 4.96 in the control group. Our expectations concerning the introduction of an additional hydrophobic ring and, as a result, increasing anticonvulsant effect of $\mathbf{1 k}$ compound, did not materialized, because a significant difference in anticonvulsant protection of animals between phenyl$\mathbf{1 a}$ and the naphthyl-substituted $\mathbf{1 k}$ derivatives was not found (Table 2).

The obtained results of 3- and 4-methoxyphenyl substituted derivatives, $\mathbf{1 g}$ and $\mathbf{1 h}$, respectively, were similar and showed a tendency of the mentioned compounds for anticonvulsant activity. It's worth mentioning that for compounds containing chlorine atoms ( $\mathbf{1 d}$ and $\mathbf{1 e}$ ), the highest lethality in animals was observed (40\% of deaths) and the highest among the studied compounds severity of seizures was determined - 3.2 points. In the present study, we were not surprised by the given results, due to results were compared to the obtained before markers concerning the influence of chlorine atoms on lethality increasing in the groups of animals. ${ }^{13}$

To sum it up, it is possible to make conclusions about advisability of implementation of free amino group into the structure of potential anticonvulsants, because 6-amino derivatives demonstrated more significant and stable results consisted of protection of experimental animals in the chemo convulsive model, compared to 6-methyl-substituted derivatives. The obtained results of pharmacological screening indicate GABA-positive properties of the synthesized acetamides.

Since the nature and mechanisms of seizures are different, "perfect" anticonvulsant should act on different models of seizures and show a multifactorial mechanism of action. The advantage of phenobarbital is its wide range of anticonvulsant effect, which is demonstrated on various models of seizures ${ }^{18}$ : PTZ, MES and kindling models, for example, amygdala kindled rat, hippocampal kindled rat and corneal kindled mouse. Structural similarity of the lead compound 2-((4-amino-6-hydroxypyrimidin-2-yl)thio)-N-(3-methylphenyl)acetamide $\mathbf{1 b}$ with phenobarbital gives reason to predict its multifactor anticonvulsant effect. To confirm this assumption, previously we carried out in silico research 
using molecular docking. The choice of targets was made in accordance with the known mechanisms of action of modern anticonvulsants.

It is known, that $\mathrm{GABA}_{\mathrm{A}} \mathrm{Rs}$ are the principal mediators of rapid inhibitory synaptic transmission in the human brain. ${ }^{25} \mathrm{~A}$ decline in $\mathrm{GABA}_{\mathrm{A}} \mathrm{R}$ signaling triggers hyperactive neurological disorders such as epilepsy. Therefore, we carried out docking study for $\mathbf{1 b}$ compound into the active $\mathrm{GABA}_{\mathrm{A}}$ site, comparing the obtained scoring function with native ligand binding results - benzamidine, which is new $\mathrm{GABA}_{\mathrm{A}} \mathrm{R}$ modulator (Table 3, Fig. 3).

Table 3. Docking results of compound $1 \mathrm{~b}$ and native ligands in anticonvulsant biotargets active sites

\begin{tabular}{|c|c|c|c|c|}
\hline Receptor & $\begin{array}{l}\text { Binding energy } \\
\text { (kcal/mol) }\end{array}$ & $\begin{array}{l}\text { Hydrophobic } \\
\text { interaction }\end{array}$ & $\begin{array}{l}\text { Hydrogen } \\
\text { interaction }\end{array}$ & \multirow{2}{*}{$\begin{array}{l}\text { Binding energy } \\
\text { (Native ligand) }\end{array}$} \\
\hline & \multicolumn{3}{|c|}{ Ligand $\mathbf{1 b}$} & \\
\hline $\begin{array}{l}\mathrm{GABA}_{\mathrm{A}} \mathrm{R} \\
\text { (4COF) }\end{array}$ & -7.5 & $\begin{array}{l}\text { Tyr205, Tyr157, } \\
\text { Ala201 }\end{array}$ & $\begin{array}{c}\text { Gln64, Ser156, } \\
\text { Tyr157, Glu155, } \\
\text { Thr176 }\end{array}$ & -8.5 (benzamidine) \\
\hline $\begin{array}{l}\mathrm{GABA}_{\mathrm{AT}} \\
(10 \mathrm{HW})\end{array}$ & -8.2 & $\begin{array}{c}\text { Cys } 135, \text { Val300, } \\
\text { Trp354 } \\
\text { Phe189, Lys329 }\end{array}$ & $\begin{array}{l}\text { His190, Ser137, } \\
\text { Phe189, Gly191, } \\
\text { Gly136, Thr353 }\end{array}$ & $\begin{array}{c}-6.7 \\
\text { (vigabatrine) }\end{array}$ \\
\hline $\begin{array}{c}\text { CA II } \\
\text { (1EOU) }\end{array}$ & -6.7 & $\begin{array}{l}\text { His64, Leu197, } \\
\text { Pro201 }\end{array}$ & $\begin{array}{l}\text { Thr199/198, } \\
\text { Pro200, His64 }\end{array}$ & $\begin{array}{c}-7.4 \\
\text { (sulfamate) }\end{array}$ \\
\hline $\begin{array}{l}\text { CA II } \\
(3 \mathrm{IEO})\end{array}$ & -5.7 & $\begin{array}{l}\text { His64 His94 Phe131 } \\
\text { Leu198 Ile91 }\end{array}$ & $\begin{array}{l}\text { Gln92, Thr200, } \\
\text { Thr199, Gln92 }\end{array}$ & $\begin{array}{c}-5.8 \\
\text { (lacosamide) }\end{array}$ \\
\hline NMDAR (5TP9). & -8.8 & $\begin{array}{l}\text { Tyr144, His273, } \\
\text { Ile128, Pro141, } \\
\text { Pro129, Val266 }\end{array}$ & Thr242 & $\begin{array}{c}-7.7 \\
\text { (felbamate) }\end{array}$ \\
\hline
\end{tabular}




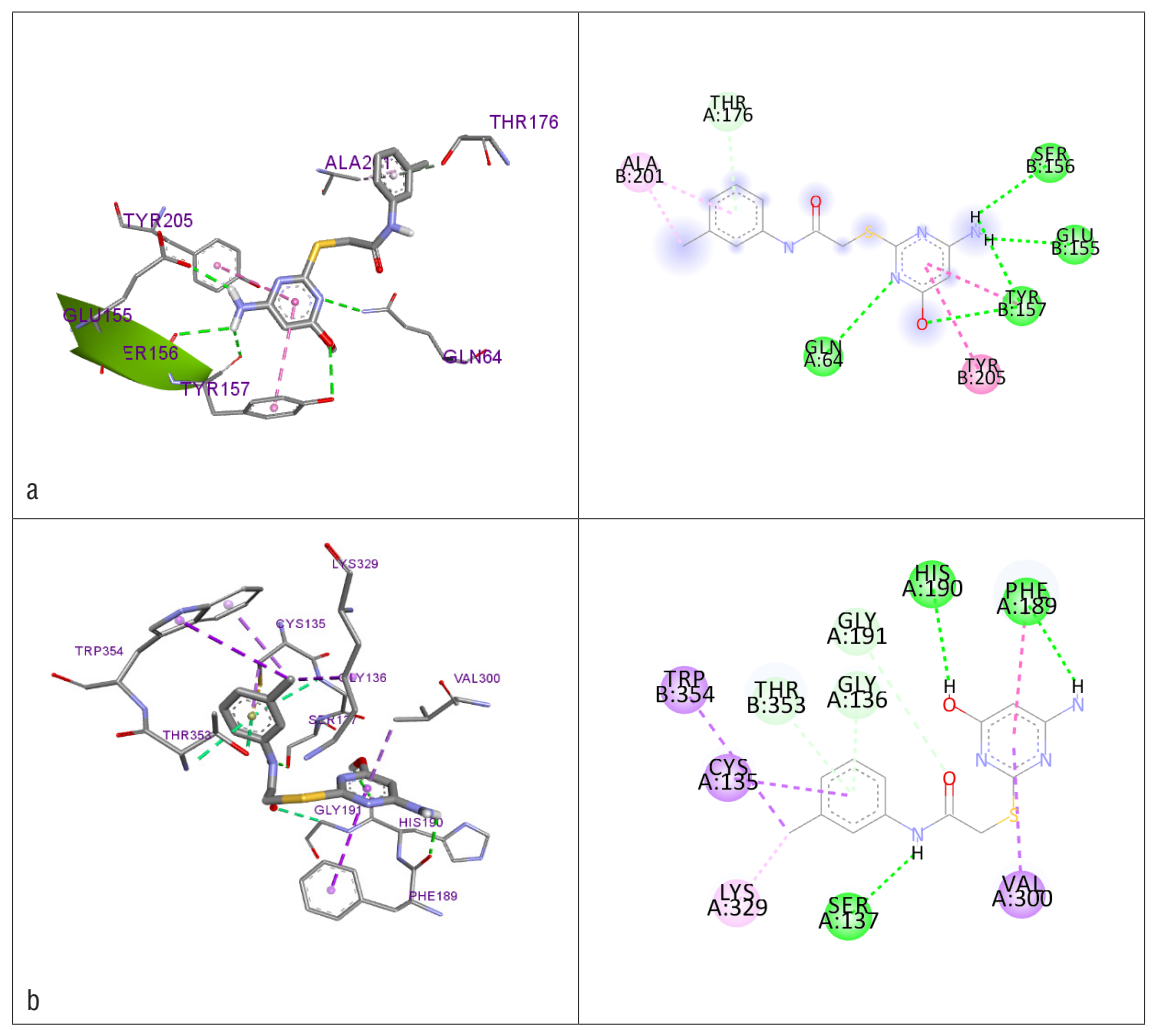

Figure 3. $2 \mathrm{D}$ and $3 \mathrm{D}$ interaction between GABAAR $\left({ }_{4} \mathrm{COF}\right)(\mathrm{a})$, GABAAT (10HW) (b) and ligand $1 \mathrm{~b}$ : hydrogen bonds are indicated by green dotted lines, hydrophobic interactions purple dotted lines.

Table 3 shows scoring functions of docking scores of the investigated studied $\mathbf{1 b}$ ligand and the native ligands with the corresponding target proteins, also it shows which amino acids of the receptor active site are involved in the interaction between ligand $\mathbf{1 b}$, and the bonds nature. As can be seen from the docking data of ligand $\mathbf{1 b}$ into $\mathrm{GABA}_{\mathrm{A}} \mathrm{R}$ protein active site, 4 hydrophobic bonds are typical for it: 2 of them are formed with alanine (Ala201) and $2-$ between the pyrimidine cycle and aromatic rings of tyrosine residues (Tyr205, 157). A significant number of hydrogen bonds with glutamine (Gln64), serine (Ser156), tyrosine (Tyr157), glutamic acid (Glu 155), and tryptophan (Thr176) are characterized by low binding energy $-7.5 \mathrm{kcal} / \mathrm{mol}$, but higher than in native ligand $-8.5 \mathrm{kcal} / \mathrm{mol}$.

It was found, that $\gamma$-Aminobutyrate aminotransferase $\left(\mathrm{GABA}_{\mathrm{AT}}\right)$ is responsible for inhibitory neurotransmitter GABA degradation, and is a target for antiepileptic drugs because its selective inhibition raises GABA concentrations in brain. ${ }^{9}$ GABA-AT exactly is irreversibly inhibited by the modern AED vigaba- 
trin ${ }^{18}$ which was used as a native ligand, and the active site coordinates were determined according to its location. Molecular docking between $\mathrm{GABA}_{\mathrm{AT}}(1 \mathrm{OHW})$ target and ligand $\mathbf{1 b}$ resulted that the studied compound is characterized by significantly less binding energy (high docking scores) with $\mathrm{GABA}_{\mathrm{AT}}(-8.2 \mathrm{kcal} /$ mol) target, comparing to the reference drug vigabatrin binding energy (-6.7 $\mathrm{kcal} / \mathrm{mol}$ ). Figure 3 points to the fact, that ligand $\mathbf{1 b}$ completely occupies the active site in the target protein and engages in hydrophobic interaction with cysteine (Cys135), valine (Val30o), tryptophan (Trp354), and phenylalanine (Phe189), and is additionally stabilized by hydrophilic bonds with residues of the following amino acids: histidine (His19o), phenylalanine (Phe189) and serine (Ser137), with carboxyl group of which the NH group of the acetamide fragment interacts. The obtained docking results show high probability of anticonvulsant activity realization of the studied 2-((4-amino-6-hydroxypyrimidin2-yl)thio)-N-(3-methylphenyl)acetamide $\mathbf{1 b}$, namely due to GABA-ergic system, especially by $\mathrm{GABA}_{\mathrm{AT}}$ inhibition.

Carbonic anhydrase II is a zinc-containing enzyme catalysing the reversible hydration of carbon dioxide. ${ }^{36}$ This reaction is essential for important physiological anion-exchange processes. Carbonic anhydrase inhibition in brain leads to $\mathrm{CO}_{2}$ accumulation and inhibition of excessive paroxysmal discharges of the neurons, which causes the drugs' antiepileptic activity. ${ }^{37,38}$ Evaluation of ligand 1b binding to the active site CA II (PDB code 1EOU) was carried out in comparison to sugar sulphamate, which is analogue of the modern and widely used AED named topiramate ${ }^{36}$, showing inhibitory effect on carbonic anhydrase. Although immersion into the target protein active site is quite deep, the formed bonds are rather strong, and there is also an additional interaction between the sulphur atom of the studied ligand $\mathbf{1 b}$ and histidine amino acid imidazole cycle, but the binding energy of compound $\mathbf{1 b}$ is higher than the one of native sulfamate ligand (- 6.7 and $-7.4 \mathrm{kcal} / \mathrm{mol}$, respectively)(Fig. 4.). 


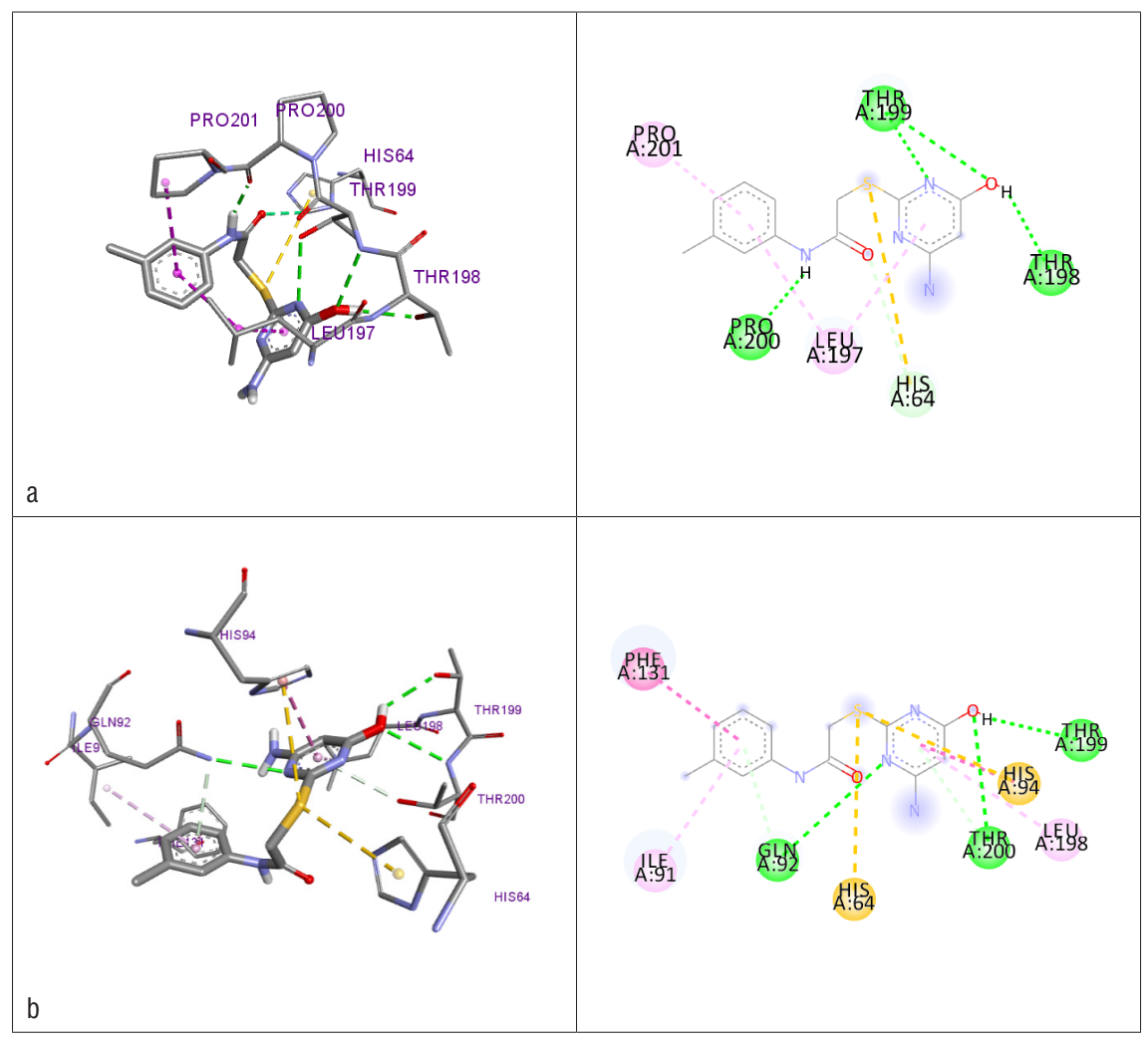

Figure 4. 3D and 2D interaction between Carbonic Anhydrase II 1EOU (a), 3IEO (b) and ligand $1 \mathrm{~b}$ : hydrogen bonds are indicated by green dotted lines, hydrophobic interactions purple dotted lines, Pi-S - orange.

It also has been found that modern AED lacosamide interacts with the coumarin site of carbonic anhydrase binding, ${ }^{39}$ which may be one of its anticonvulsant activity mechanisms. Docking study of 2-((4-amino-6-hydroxypyrimidin-2-yl) thio)-N-(3-methylphenyl)acetamide $\mathbf{1 b}$ into coumarinic site of carboxylic anhydrase (PDB code 3 IEO) demonstrated affinity to the mentioned protein at the reference drug level: -5.7 and $-5.8 \mathrm{kcal} / \mathrm{mol}$, respectively. Hydrophobic bonds between ligand $\mathbf{1 b}$ and phenylalanine (Phe131), leucine (Leu198) and isoleucine (Ile91), and hydrophilic ones with glycine (Gln92), tryptophan (Thr200 and Thr199) form stable conformation, which is also being stabilized by two Pi-S bonds between the thio group of ligand $\mathbf{1 b}$ and the imidazole cycle of histidine 64 and 94. It should be noted that, as in lacosamide case, there was no interaction with zinc ions Zn (II) in adduct CA II-ligand $\mathbf{1 b}$. Obtained calculations show that compound $\mathbf{1 b}$ anticonvulsant activity by its inhibition mechanism of carbonic anhydrase II is less reliable than GABA aminotransferase inhibition. 
$\mathrm{N}$-methyl-D-aspartate receptor (NMDAR) is an ionotropic glutamate receptor, gated by the endogenous co-agonists glutamate and glycine, permeable to $\mathrm{Ca}+$ and $\mathrm{Na}+$. NMDAR dysfunction is associated with numerous neurological and psychiatric disorders, including schizophrenia, depression, Alzheimer's disease and epilepsia. ${ }^{40}$ To predict the possibility of glutamatergic mechanism of anticonvulsant activity of the studied pyrimidine derivative $\mathbf{1 b}$, its affinity for the active site NMDAR (PDB code 5TP9) was determined (Fig. 5).

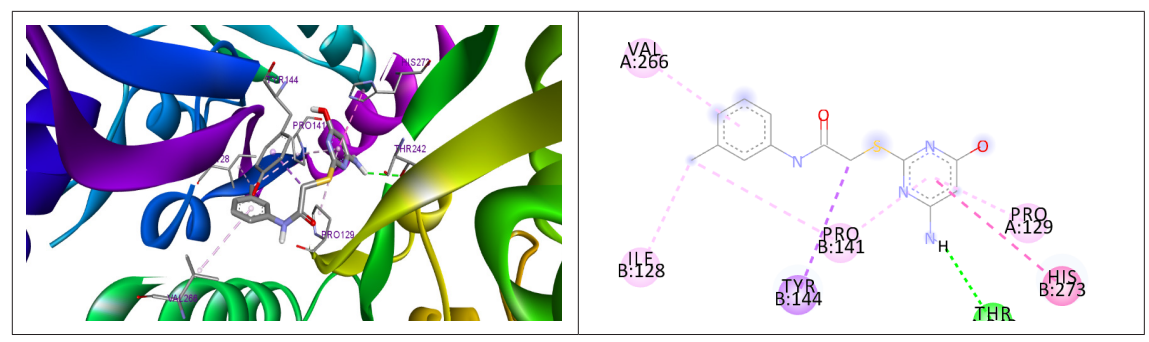

Figure 5. 3D and 2D interaction between NMDAR (5TP9) and ligand 1b: hydrogen bonds are indicated by green dotted lines, hydrophobic interactions - purple dotted lines.

Deep immersion into NMDA receptor hydrophobic pocket with formation of strong hydrophobic bonds (distance $\AA \leq 5$ ) was found: between $\mathrm{CH}_{2}$ group and tyrosine aryl ring (Tyr144), between the pyrimidine cycle of compound $\mathbf{5 . 2}$ and histidine imidazole fragment (His273), methyl radical of the acetamide residue and isoleucine (Ile128), and proline pyrrolidine fragment (Pro141), compound 1b pyrimidine cycle, and proline pyrrolidine residues 141 and 129, the ligand phenyl radical, and valine (Val266). Ligand $\mathbf{1 b}$ forms only one hydrophobic bond between tryptophan oxygen atom (Thr242) and ligand 5.2 amino group (distance 2,78 $\AA$ ). Scoring function points to high affinity of ligand $\mathbf{1 b}$ to NDMA receptor active site: $-8.8 \mathrm{kcal} / \mathrm{mol}$ (Tabl. 3.), while a known inhibitor of NDMA receptor felbamate is characterized by $-7.7 \mathrm{kcal} / \mathrm{mol}$ value. Considering that, anticonvulsant activity of compound $\mathbf{1 b}$ by its inhibitory effect on glutamate NDMA receptor is quite probable.

According to in silico ADMET analysis and docking into the active $\mathrm{GABA}_{\mathrm{A}}$ receptor site, synthesis of 2-(4-amino-6-hydroxy-pyrimidin-2-yl)thio-N-acetamides as a potential anticonvulsants was scheduled. The synthesis was carried out by 6-amino-2-thiopyrimidine alkylation with appropriate 2- chloroacetamides in DMF environment in potassium carbonate presence. According to the TLC, mass-spectroscopy and ${ }^{1} \mathrm{H}$ NMR-spectroscopy data, the corresponding thioacetamide derivatives were alkylation products. All the synthesized compounds have shown a tendency to anticonvulsant activity on the model of pentylenetetrazole seizures in rats. Positive effect on anticonvulsant activity of pyrimidine 
cycle amino group in the 6 position was found. The estimated affinity of the lead compound to anticonvulsant biotargets allows providing a multifactor mechanism for anticonvulsant activity implementation: due to the inhibitory effect on GABA aminotransferase and the ionotropic glutamate receptor NMDA. The obtained in vivo data and in silico calculations substantiate the prospect of indepth study of the anticonvulsant and concomitant pharmacological and toxicological properties of the lead compound 2-((4-amino-6-hydroxypyrimidin2-yl)thio)-N-(3-methylphenyl)acetamide. 


\section{REFERENCES}

1. Vossler, D. G.; Weingarten, M.; Gidal, B. E. Summary of antiepileptic drugs available in the United States of America: working toward a world without epilepsy. Epilepsy Curr. 2018, 18, $1-26$.

2. Goldenberg, M. M. Overview of drugs used for epilepsy and seizures: etiology, diagnosis, and treatment. Pharm. Ther. 2010, 35, 392-415.

3. Beleza, P. Refractory epilepsy: a clinically oriented review. Eur. Neurol. 2009, 62, 65-71.

4. Laxer, K. D.; Trinka, E.; Hirsch L. J.; Cendes, F.; Langfitt, J.; Delanty, N.; Resnick, T.; Benbadis, S. R. The consequences of refractory epilepsy and its treatment. Epilepsy Behav. 2014, 37, 59-70.

5. Khan, N.; Kulsoom, S.; Rashid, H. Ligand based pharmacophore model development for the identification of novel antiepileptic compound. Epilepsy Res. 2012, 98, 62-71.

6. Malawska, B. Application of pharmacophore models for the design and synthesis of new anticonvulsant drugs. Mini Rev. Med. Chem. 2003, 3, 341-348.

7. McCabe, P. H. New anti-epileptic drugs for the 21stcentury. Expert Opin. Pharmacother. 2000. 1, 633-674.

8. Sankaraneni, R.; Lachhwani, D. Antiepileptic Drugs-A Review. Pediatric Annals. 2015, 44, $36-42$.

9. Storici, P.; Capitani, G.; Baise, D. D.; Moser, M.; John, R. A. Jansonius, J. N., Schirmer, T. Crystal structure of GABA aminotransferase, a target for antiepileptic drug therapy. Biochemistry, 1999, 38, 8628-34.

10. Goto, M.; Miyahara, I.; Hirotsu, K.; Conway, M.; Yennawar, N.; Islam, M.; Hutson, S. M. Structural Determinants for Branched-chain Aminotransferase Isozyme-specific Inhibition by the Anticonvulsant Drug Gabapentin. J. Biolog. Chem. 2005, 280, 37246-37256.

11. Hubert, P.; Parain, D.; Vallée, L. Management of convulsive status epilepticus in infants and children. Rev Neurol (Paris). 2009, 165, 390-397.

12. Zhang, Q.; Yu, Y.; Lu, Y.; Yue, H. Systematic review and meta-analysis of propofol versus barbiturates for controlling refractory status epilepticus. BMC Neurology. 2019, 19, 1-22.

13. Severina, H.; Skupa, O.; Khairulin, A.; Voloschuk, N.; Georgiyants, V. A. Synthesis and anticonvulsant activity of 6-methyl-2-thioxo-2,3-dihydropyrimidin-4(1H)-one acetamides. J. App. Pharm. Scie. 2019, 9, 12-19.

14. El Kayal, W. M.; Shtrygol, S. Y.; Zalevskyi, S. V.; Shark, A. A.; Tsyvunin, V. V.; Kovalenko, S.M.; Bunyatyan, N.D.; Perekhoda, L.O.; Severina, H.I.; Georgiyants, V.A. Synthesis, in vivo and in silico anticonvulsant activity studies of new derivatives of 2-(2,4-dioxo-1,4-dihydroquinazolin-3(2H)-yl)acetamide. Eur J Med Chem. 2019, 180, 134-142.

15. Danielson, M. L.; Hu, B.; Shen, J.; Desai, P.V. In silico ADME techniques used in early-phase drug discovery. In: Bhattachar, S.N., Morrison, J.S., Mudra, D.R., Bender, D.M. (eds) Translating Molecules into Medicines. Springer Nature, Cham, Switzerland, 2017, 81-117.

16. Daina, A.; Michielin, O.; Zoete, V. Swiss ADME: a free web tool to evaluate pharmacokinetics, drug-likeness and medicinal chemistry friendliness of small molecules. Sci. Rep. 2017, 7, 1-13.

17. Protein Data Bank. http://www.rcsb.org/pdb/home/home.do

18. Bialer, M.; White, H. S. Key factors in the discovery and development of new antiepileptic drugs. Nat. Rev. Drug Discov. 2010, 9, 68-82. 
19. Trott, O.; Olson, A. J. AutoDock Vina: improving the speed and accuracy of docking with a new scoring function, efficient optimization, and multithreading. J. Comput. Chem., 2010, 31, 455-461.

20. Taylor, E. C.; Cheng, C. C. Studies in Purine Chemistry. VII. An Improved Synthesis of Hypoxanthine. J. Org. Chem., 1960, 25, 148-149.

21. Fisher, R. S. Animal models of the epilepsies. Brain Research Reviews. 1989, 14, 245-278.

22. Loscher, W.; Fiedler, M. The role of technical, biological and pharmacological factors in the laboratory evaluation of anticonvulsant drugs. VI. Seasonal influences on maximal electroshock and pentylenetetrazole seizure thresholds. Epilepsy Res. 1996, 25, 3-10.

23. Gerald, M. C.; Riffee, W. H. Acute and chronic effects of d- and l-amphetamine on seizure susceptibility in mice. Eur. J. Pharmacol. 1973, 21, 323-330.

24. Matias, M.; Campos, G.; Silvestre, S.; Falcão, A.; Alves, G. Early preclinical evaluation of dihydropyrimidin(thi)ones as potential anticonvulsant drug candidates. Eur. J. Pharm. Sci. 2017, 102, 264-274.

25. Miller, P. S.; Aricescu, A. R. Crystal structure of a human GABAA Receptor. Nature, 2014, 512, 270-275.

26. Kelder, J.; Grootenhuis, P.D.J.; Bayada, D. M.; Delbressine, L. P.C.; Ploemen, J. Polar Molecular Surface as a Dominating Determinant for Oral Absorption and Brain Penetration of Drugs. Pharm. Res. 1999, 16, 1514-1519.

27. Hansch, C.; Dunn, W. J. Linear Relationships between lipophilic character and biological activity of drugs. J. Pharm. Sci. 1972, 61, 1-19. 28. Lipinski, C. A.; Lombardo, F.; Dominy, B. W.; Feeney, P. J. Experimental and computational approaches to estimate solubility and permeability in drug discovery and development settings. Adv. Drug. Deliv. Rev. 2001, 46, 3-26.

29. Lipinski, C. A. Rule of five in 2015 and beyond: target and ligand structural limitations, ligand chemistry structure and drug discovery project decisions. Adv. Drug Deliv. Rev. 2016, $101,34-41$.

30. Szakacs, G.; Varadi, A.; Ozvegy-Laczka, C.; Sarkadi, B. The role of ABC transporters in drug absorption, distribution, metabolism, excretion and toxicity (ADME-Tox). Drug Discov. Today, 2008, 13, 379-393.

31. Wang, G. X.; Wang, D. W.; Liu, Y.; Ma, Y. H.; Intractable epilepsy and the Pglycoprotein hypothesis. Int. J. Neurosci. 2016, 126, 385-392.

32. Saldaña-Cruz, A. M.; Sánchez-Corona, J.; Márquez de Santiago, D. A.; García-Zapién, A.G.; Flores-Martínez, S.E. Pharmacogenetics and antiepileptic drug metabolism: implication of genetic variants in cytochromes P450. Rev Neurol. 2013, 56, 471-9.

33. Crepaldi, P.; Cacciari, B.; Bonache, M. C.; Spalluto, G.; Varani, K.; Borea, P. A.; Kügelgen, I.; Hoffmann, K.; Pugliano, M.; Razzari, C.; Cattaneo, M. 6-Amino-2-mercapto-3H-pyrimidin4-one derivatives as new candidates for the antagonism at the P2Y12 receptors. Bioorg Med Chem. 2009. 17, 4612-21.

34. Cosimelli, B.; Greco, G.; Ehlardo, M.; Novellino, E.; Settimo, F.; Taliani, S.; La Motta, C.; Bellandi, M.; Tuccinardi. N.; Martinelli, A.; Ciampi, O.; Trincavelli, M.L.; Martini C. Derivatives of 4-amino-6-hydroxy-2-mercaptopyrimidine as novel, potent, and selective A3 adenosine receptor antagonists. J. Med. Chem. 20o8, 51, 1764-1770.

35. Kigundi, A. M.; Ozerov, A. A.; Novikov, M. S. Alkylation of 6-methyl-2-thiouracile

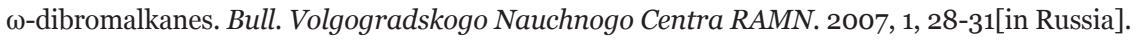


36. Recacha, R.; Costanzo, M. J.; Maryanoff, B. E.; Chattopadhyay, D. Crystal structure of human carbonic anhydrase II complexed with anticonvulsant sugar sulfamate. Molecules, 2017, 22, 1094-2003.

37. Supuran, C.T. Carbonic anhydrase inhibitors and activators for novel therapeutic applications. Future Med. Chem. 2011, 3, 1165-1180.

38. Karataş, M. O.; Uslu, H.; Sarı, S.; Alagöz, M. A.; Karakurt, A.; Alıcı, B.; Bilen, C.; Yavuz, E.; Gencer, N.; Arslan, O. Coumarin or benzoxazinone based novel carbonic anhydrase inhibitors: synthesis, molecular docking and anticonvulsant studies. J. Enzym. Inhib. Med. Chem. 2016, $31,760-772$.

39. Temperini, C.; Innocenti, A.; Scozzafava, A.; Parkkila S.; Supuran C. T. The coumarin-binding site in carbonic anhydrase accommodates structurally diverse inhibitors: the antiepileptic lacosamide as an example and lead molecule for novel classes of carbonic anhydrase inhibitors. J. Med. Chem. 2010, 53, 850-854.

40. Villemure, E.; Volgraf, M.; Jiang, Y.; Wu, G.; Ly, C. Q.; Yuen, P. W.; Lu, A.; Luo, X.; Liu, M.; Zhang, S.; Lupardus, P. J.; Wallweber, H. J.; Liederer, B. M.; Deshmukh, G.; Plise, E.; Tay, S.; Wang, T. M.; Hanson, J. E.; Hackos, D. H.; Scearce-Levie, K.; Schwarz, J.B.; Sellers, B.D. GluN $_{2} \mathrm{~A}$-Selective pyridopyrimidinone series of NMDAR positive allosteric modulators with an improved in vivo profile. Med. Chem. Lett. 2017, 8, 84-89. 